\title{
DEVELOPMENT OF MICROMORPH TANDEM SOLAR CELLS ON FLEXIBLE LOW COST PLASTIC SUBSTRATES
}

\author{
F.-J. Haug, V. Terrazzoni-Daudrix, T. Söderström, X. Niquille, C. Ballif \\ Institute of Microtechnology, University of Neuchâtel, \\ Rue A.-L. Breguet 2, CH 2000 Neuchatel, Switzerland
}

\begin{abstract}
We report on the development of fully flexible micromorph tandem solar cells directly on low cost substrates like PET and PEN. The cells are deposited in nip/nip configuration on the plastic substrate coated with a highly reflecting Ag-ZnO back contact. Light trapping is achieved by combining a periodically textured substrate and a diffusing $\mathrm{ZnO}$ front contact. Single junction microcrocystalline cell with a stable efficiency of $8.6 \%$ and $8.4 \%$ are achieved with i-layer thickness of 1.8 and $1.2 \mu \mathrm{m}$ respectively. In tandem devices we obtain an efficiency of $10.9 \%$ (initial) with an open circuit voltage of $1.35 \mathrm{~V}$ and a FF of $71.5 \%$. These cells are slightly top limited with 11.26 and 11.46 $\mathrm{mA} / \mathrm{cm} 2$ in the amorphous (270 nm thick) and the microcrystalline sub-cells (1.2 $\mu \mathrm{m}$ thick), respectively. We introduce an intermediate reflector between the bottom and the top cell because it allows increasing the top cell current without compromising stability by a thicker absorber. We present results on ex-situ $\mathrm{ZnO}$ and a new material, a low refractive index P-doped siliconoxygen compound deposited in-situ by plasma process, in the same reactor as the micromorph cell.
\end{abstract}

\section{INTRODUCTION}

Thin film silicon is a proven and reliable material for photovoltaic energy production. Several manufacturers have shown the suitability of amorphous silicon for medium and large scale production modules on rigid glass substrates. High conversion efficiencies are obtained by the use of multijunction devices made from amorphous silicon and a material with lower band gap like microcrystalline silicon in so-called micromorph tandems [1, 2], or silicon-germanium alloys [3]. In the continuing effort towards lower module cost, roll to roll processing on flexible substrates is an attractive route because the production equipment requires less floor space and allows generally a high throughput. Additionally, the availability of flexible modules opens new possibilities for the application of photovoltaics like easier deployment and better building integration. Current substrate materials for the fabrication of flexible thin film silicon based modules include stainless steel substrates [3], [4], polyimides [5], and sacrificial aluminium substrates that require a subsequent etching [6]. Following rigorously the aim of low production cost, we present the development of micromorph tandem solar cells directly on fully flexible and low cost plastic substrates like PEN and PET.

\section{EXPERIMENTAL}

We use low cost plastic substrate materials like poly-ethylen-terephtalate (PET) and -naphtalate (PEN). In order to achieve an efficient light trapping, the substrates are textured with a proprietary roll to roll replication process which can reproduce a wide variety of arbitrary shapes [7]. We chose to use a periodic substrate structure which has shown excellent light trapping properties for a wide spectral range [8]. A highly reflective back contact is then deposited on the textured substrates in a roll to roll sputtering process [9]. It consists of $\mathrm{Ag}-\mathrm{ZnO}$ double layer which conformally covers the substrate structure.

The thin film silicon layers are grown in a n-i-p sequence by plasma enhanced chemical vapour deposition (PE-CVD) at deposition temperatures between 150 and $180^{\circ} \mathrm{C}$. We are using silane $\left(\mathrm{SiH}_{4}\right)$ and hydrogen $\left(\mathrm{H}_{2}\right)$ for the intrinsic absorber layer, for the nand p-doped layers we add phosphine $\left(\mathrm{PH}_{3}\right)$ and trimethyl-boron (TMB), respectively. The plasma excitation is in the very high frequency (VHF) domain between 70 and $140 \mathrm{MHz}$, and it is capacitively coupled to the parallel plate reaction chamber. All the thin film silicon processing is carried out on laboratory scale with stationary processes on small areas of $8 \times 8$ $\mathrm{cm}^{2}$, but we restrict our development to regimes that are easily transferable into roll to roll processes at the site of an industrial partner (VHF technologies, Yverdon)

Finally, the front contact consists of B-doped $\mathrm{ZnO}$ deposited by low pressure CVD. It is fabricated with a random surface texture which aids in the light trapping. For reference purposes we also use sputtered ITO contacts with a thickness of $70 \mathrm{~nm}$.

All the results presented in this contribution have been obtained without conducting grid on the TCO, and without antireflection coating for current enhancement.

The open circuit voltage $\left(\mathrm{V}_{\mathrm{oc}}\right)$ and the fill factor $(\mathrm{FF})$ of the solar cells are determined from the current- 
voltage $(\mathrm{j}-\mathrm{V})$ characteristics measured under a simulated AM1.5 spectrum (WakomWXS-140-10). The short circuit current density $\left(\mathrm{j}_{\mathrm{sc}}\right)$ is determined separately by integration over the external quantum efficiency weighted with the AM1.5 spectrum. This procedure avoids ambiguities that arise from the determination of the cell area. In tandem cell, for calculation of the efficiency, the limiting current is taken.

\section{SOLAR CELL RESULTS}

\section{1 microcrystalline bottom cells}

Our development of flexible microcrystalline solar cells is mostly concerned with establishing a robust and reproducible process for bottom cells with their later application to tandem cells. Figure 1 shows the $\mathrm{j}-\mathrm{V}$ characteristic of a typical microcrystalline bottom cell processed on a periodically textured plastic substrate. For reference it has been finished with the LPCVD front contact instead of the top cell. Using thin absorber layers of $1.2 \mu \mathrm{m}$ we are able to obtain short circuit currents up to $23.4 \mathrm{~mA} / \mathrm{cm}^{2}$. With typical open circuit voltages of $520 \mathrm{mV}$ and fill factors between 70 and $71 \%$ the resulting efficiency is about $8.4 \%$. From Figure 1 it is observed that the microcrystalline cell shows no degradation after $1000 \mathrm{~h}$ of continuous illumination at $50^{\circ} \mathrm{C}$.

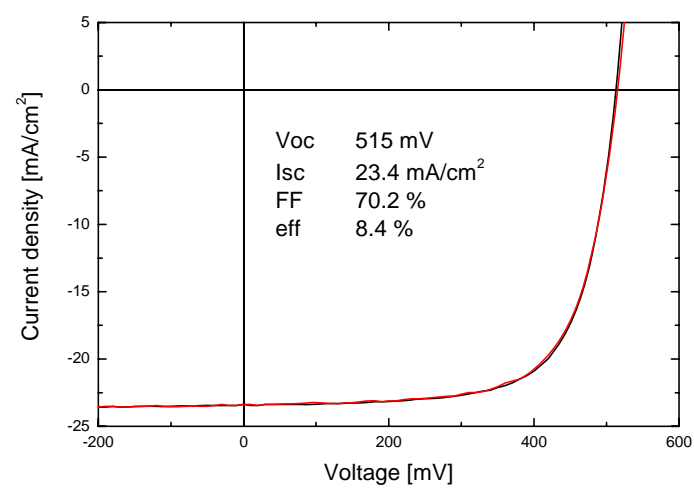

Figure 1: Current voltage characteristic of a micromorph bottom cell before and after exposure to $1000 \mathrm{~h}$ of illumination at $50^{\circ} \mathrm{C}$.

By using a dilution grading for the i-layer that follows more closely the microcrystalline to amorphous transition throughout the i-layer, we have also achieved efficiencies of $8.6 \%$ with $\mathrm{Voc}=515 \mathrm{mV}, \mathrm{Jsc}_{\mathrm{sc}}=23.85$ $\mathrm{mA} / \mathrm{cm} 2$ and $\mathrm{FF}=70 \%$ :. However, for the development of tandem cells we currently focus on a bottom cell process that is kept as simple as possible.

\section{2 amorphous single cells}

Recently it was shown that fill factor and open circuit voltage losses in amorphous cells on textured substrates are less severe when an amorphous Si-C nlayer is used instead of a microcrystalline n-layer [10]. The development of these cells was not carried out on the periodically textured substrate, but on a flexible PEN substrate coated with a flat Ag reflector followed by textured LPCVD-ZnO. This structure was found very useful for fabricating a wide variety of different surface morphologies by either changing the properties of the $\mathrm{ZnO}$ layer, or by employing an additional treatment of the $\mathrm{ZnO}$ surface. The external quantum efficiencies of cells obtained on this structure and on a flat reference are shown in Figure 2.

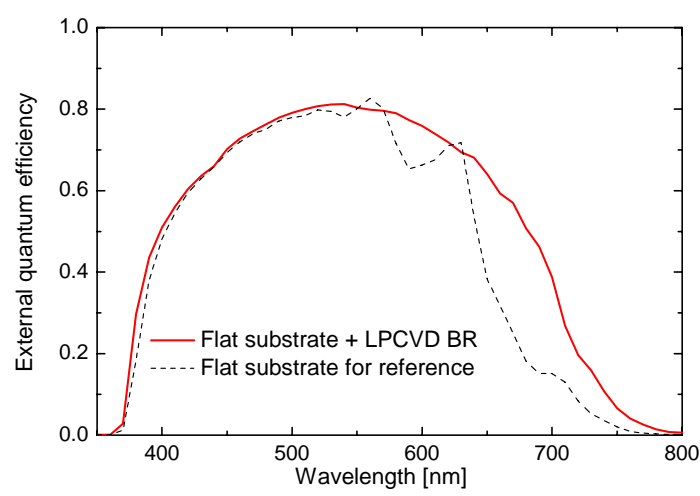

Figure 2: External quantum efficiency of amorphous solar cells on flat and textured substrate

The nominal i-layer thickness of the amorphous cells in this development is kept constant at $270 \mathrm{~nm}$, the player consists of microcrystalline silicon. The initial performances of cells on flat and textured substrates are summarized in Table I.

Table I: Solar cell parameters of n-i-p amorphous solar cells on flat and textured substrate on plastic.

\begin{tabular}{|l||l|l|l|l|}
\hline & $\begin{array}{l}\text { Voc } \\
{[\mathrm{mV}]}\end{array}$ & $\begin{array}{l}\mathrm{jsc} \\
{\left[\mathrm{mA} / \mathrm{cm}^{2}\right]}\end{array}$ & $\begin{array}{l}\text { FF } \\
{[\%]}\end{array}$ & $\begin{array}{l}\eta \\
{[\%]}\end{array}$ \\
\hline \hline flat & 895 & 12.3 & 66 & 7.3 \\
\hline flat+ZnO & 888 & 14.3 & 70 & 8.8 \\
\hline
\end{tabular}

\section{3 micromorph tandem cells}

We combined the developments outlined in the previous two sections for the development of micromorph tandem solar cells. Figure 3 shows the external quantum efficiency of the top and bottom cell in a tandem device. The respective thicknesses of the cells are $1.2 \mu \mathrm{m}$ and $270 \mathrm{~nm}$. Additionally, the figure includes the microcrystalline and amorphous single cell references from the same deposition.

In the region of long wavelengths where the top cell is transparent, the quantum efficiency shows hardly any difference between the bottom reference and the tandem. Similarly, the blue response of the amorphous reference is very close to that of the tandem cell. 
However, the blue response of the microcrystalline reference cell in Figure 3 clearly shows that there is potential for gaining current into the top cell. In total we find a difference of $0.7 \mathrm{~mA}$ between the microcrystalline reference and the added currents of this tandem structure. We think that this difference is due to the differences in the nucleation of the microcrystalline p-layer that depend on the underlying material. On the microcrystalline cell it is easier to nucleate and grow a p-layer of high conductivity; hence a thinner layer with fewer losses is sufficient.

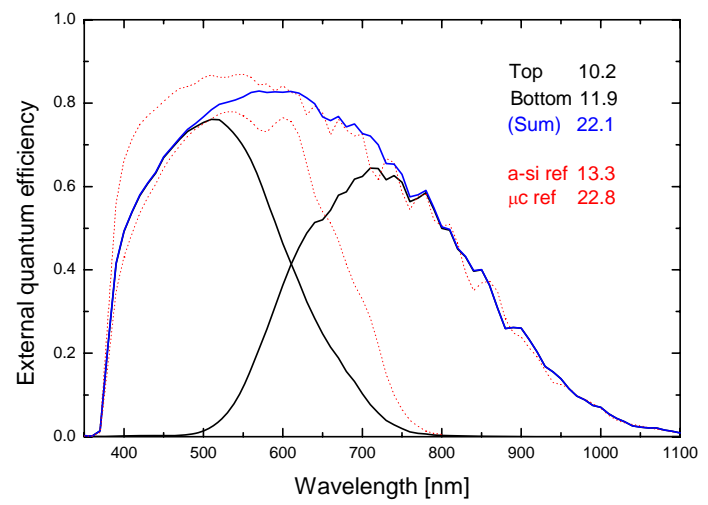

Figure 3: External quantum efficiencies of a micromorph tandem cell together with microcrystalline and amorphous reference cells from the same depositions.

\subsection{Intermediate reflector development}

After improving the top cell process and its p-layer in particular, we were able to obtain a tandem cell efficiency of $10.9 \%$ (initial) with an open circuit voltage of $1.35 \mathrm{~V}$ and a FF of $71.5 \%$. Figure 4 shows that at this state of development there is still a slight top limitation with 11.26 and $11.46 \mathrm{~mA} / \mathrm{cm}^{2}$ in the amorphous and the microcrystalline sub-cells, respectively.

In order to further enhance the top cell current without compromising its stability by increasing its absorber layer thickness, an additional intermediate reflector (IR) layer between the bottom and the top cell of the tandem has been used [11]. Often a 60 to $70 \mathrm{~nm}$ thick layer of doped zinc oxide is used for this purpose because $\mathrm{ZnO}$ is a well established material in solar cell processing, and its refractive index of around two is well suited [12].

Figure 4 shows that this layer is capable of improving the photocurrent of the top cell between 550 and $700 \mathrm{~nm}$. The photocurrent in the top cell is enhanced by about $0.4 \mathrm{~mA} / \mathrm{cm}^{2}$. However, by adding up the current densities we find a reduction from 22.72 $\mathrm{mA} / \mathrm{cm}^{2}$ without reflector to $21.93 \mathrm{~mA} / \mathrm{cm}^{2}$ in the structure with the $\mathrm{ZnO}$ intermediate layer. Additionally, the solar cell characteristics in Table II indicate poor cell performance due to shunting.
Table II: Solar cell parameters of a micromorph nip tandem on plastic with $\mathrm{ZnO}$ intermediate reflector.

\begin{tabular}{|l||l|l|l|l|}
\hline int. refl. & $\begin{array}{l}\text { Voc } \\
{[\mathrm{mV}]}\end{array}$ & $\begin{array}{l}\text { jsc(top)/jsc(btm) } \\
{\left[\mathrm{mA} / \mathrm{cm}^{2}\right]}\end{array}$ & $\begin{array}{l}\text { FF } \\
{[\%]}\end{array}$ & $\begin{array}{l}\eta \\
{[\%]}\end{array}$ \\
\hline \hline without & 1.35 & $11.26 / 11.46$ & 71.5 & 10.9 \\
\hline with $\mathrm{ZnO}$ & 1.23 & $11.84 / 10.09$ & 56 & 6.9 \\
\hline
\end{tabular}

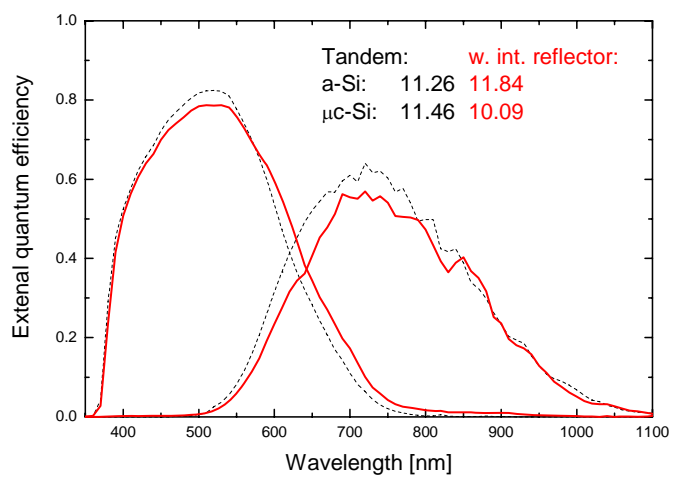

Figure 4: Micromorph tandem cell with intermediate $\mathrm{ZnO}$ reflector (co-deposition).

It is very well possible that we could overcome the shunting problem by a better process control, but there are some inherent drawbacks with the $\mathrm{ZnO}$ layer; it has been suggested that the conductive $\mathrm{ZnO}$ layer could pose interconnection problems when cells are series connected into modules [13, 14]. Additionally, the interruption of the silicon deposition processes for the ex-situ fabrication of the $\mathrm{ZnO}$ layer is undesirable.

Recently, the successful application of phosphorous doped silicon oxide compounds was reported for micromorph tandem cells on rigid and flexible substrates $[10,15,16]$. Figure 5 presents the redistribution of the absorption between bottom and top cells with this new intermediate reflector structure. In this case we find somewhat higher losses; the added current densities drop from $23.8 \mathrm{~mA} / \mathrm{cm}^{2}$ without IR to $22.6 \mathrm{~mA} / \mathrm{cm}^{2}$ in the structure with the $\mathrm{Si}-\mathrm{O}$ intermediate layer.

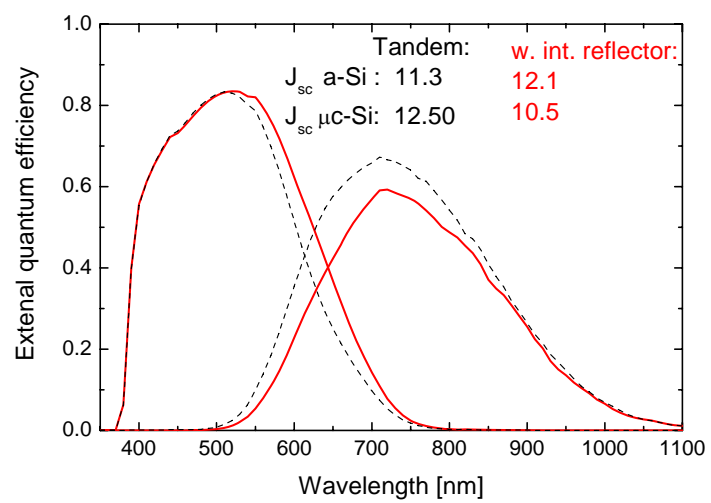

Figure 5: Micromorph tandem cell with intermediate $\mathrm{Si}-\mathrm{O}$ reflector (co-deposition). 
The solar cell parameters of the micromorph tandem cell with the new Si-O IR are given in Table III and are similar to those without IR. We are confident that we can achieve current matching by increasing the bottom cell thickness. Assuming the same solar cell data with a matched current of $12.1 \mathrm{~mA} / \mathrm{cm}^{2}$, the potential efficiency exceeds $11.2 \%$.

Table III: Solar cell parameters of a micromorph tandem with Si-O IR.

\begin{tabular}{|l||l|l|l|l|}
\hline int. refl. & $\begin{array}{l}\text { Voc } \\
{[\mathrm{mV}]}\end{array}$ & $\begin{array}{l}\text { jsc(bt)/jsc(top) } \\
{\left[\mathrm{mA} / \mathrm{cm}^{2}\right]}\end{array}$ & $\begin{array}{l}\text { FF } \\
{[\%]}\end{array}$ & $\begin{array}{l}\eta \\
{[\%]}\end{array}$ \\
\hline \hline without & 1.37 & $12.5 / 11.3$ & 67 & 10.4 \\
\hline with Si-O & 1.36 & $10.5 / 12.1$ & 68 & 9.7 \\
\hline
\end{tabular}

\section{CONCLUSIONS}

We have presented our progress in single junction nip thin film silicon solar cells. In particular, we identified a periodic texture for the back contact of microcrystalline solar cells that yields more than $23 \mathrm{~mA} / \mathrm{cm} 2$ on thin absorbers of only $1.2 \mu \mathrm{m}$ thickness. For amorphous solar cells we developed an amorphous $\mathrm{Si}-\mathrm{C}$ n-layer that yields high Voc on a variety of structured substrates. The combination of these results into tandem cells resulted in initial efficiencies of $10.9 \%$. By the introduction of intermediate reflector layers of $\mathrm{ZnO}$ or based on Si-O made by PECVD, we could increase the top cell current without increasing its thickness. Our future work will address improvements in the reflector layer, in current matching and in electrical parameters.

\section{ACKNOWLEDGEMENTS}

This work was performed within the EU-Project "Flexcellence" under contract 019948 . We would like to acknowledge M. Fahland from the FEP Dresden for the fabrication of the back reflectors.

\section{REFERENCES}

[1] J. Meier, S. Dubail, R. Flückinger, D. Fischer, H. Keppner, and A. Shah, in 1st World PVSEC, Hawaii, 1994, p. 409.

[2] K. Yamamoto, M. Yoshimi, T. Suzuki, T. Nakata, T. Sawada, A. Nakajima, and K. Hayashi, in 28th IEEE PVSC, Anchorage, 2000, p. 1428.

[3] J. Yang, A. Banerjee, and S. Guha, Applied Physics Letters 70 (1997) 2975.

[4] K. Saito, M. Sano, H. Otoshi, A. Sakai, S. Okabe, and K. Ogawa, in 3rd World PVSEC, Osaka, 2003.
[5] M. Tanda, K. Tabuchi, M. Uno, S. Kato, Y. Takeda, S. Iwasaki, Y. Yokohama, T. Wada, M. Shimosawa, Y. Sakakibara, A. Takano, H. Nishihara, H. Enomoto, and T. Kamoshita, in 31st IEEE PVSC, IEEE, Lake Buona Vista, 2005, p. 1560 .

[6]R. Schlatman, B. Stannowski, E. A. G. Hamers, J. M. Lenssen, A. G. Talma, R. Bartl, and G. J. Jongerden, in 21st European PVSEC, Dresden, 2006, p. 1587.

[7] J. Bailat, V. Terrazzoni-Daudrix, J. Guillet, F. Freitas, X. Niquille, A. Shah, C. Ballif, T. Scharf, R. Morf, A. Hansen, D. Fischer, Y. Ziegler, and A. Closset, in 20th European PVSEC, Barcelona, 2005.

[8] F.-J. Haug, V. Terrazzoni-Daudrix, T. Söderström, X. Niquille, J. Bailat, and C. Ballif, in 21st European PVSEC, Dresden, 2006.

[9] M. Fahland, V. Kirchhoff, C. Charton, and P. Karlsson, in 43rd Technical conference of the society of vacuum coaters, Denver, 2000, p. 357.

[10] T. Söderström, F.-J. Haug, V. Terrazzoni-Daudrix, X. Niquille, S. Perregeaux, M. Fahland, and C. Ballif, in 22nd European PVSEC, Milan, 2007.

[11] D. Fischer, S. Dubail, J. D. Anna Selvan, N. Pellaton Vaucher, R. Platz, C. Hof, U. Kroll, J. Meier, P. Torres, H. Keppner, N. Wyrsch, M. Goetz, A. Shah, and K.-D. Ufert, in 25 IEEE PVSC, Washington D. C., 1996, p. 1053.

[12] D. Dominé, J. Bailat, J. Steinhauser, A. Shah, and C. Ballif, in 4th World PVSEC, Hawaii, 2006, p. 1465 .

[13] J. Meier, J. Spitznagel, S. Faÿ, C. Bucher, U. Graf, U. Kroll, S. Dubail, and A. Shah, in 29th IEEE PVSC, New Orleans, 2002, p. 11181121.

[14] K. Yamamoto, A. Nakajima, M. Yoshimi, T. Sawada, S. Fukuda, and K. Hayashi, in 29th IEEE PVSC, New Orleans, 2002, p. 1110.

[15] P. Buehlmann, J. Bailat, D. Dominé, A. Billet, F. Meillaud, A. Feltrin, and C. Ballif, submitted to Applied Physics Letters (2007)

[16] A. Lambertz et.al., in 22nd EUPVSEC, Milan, 2007. 